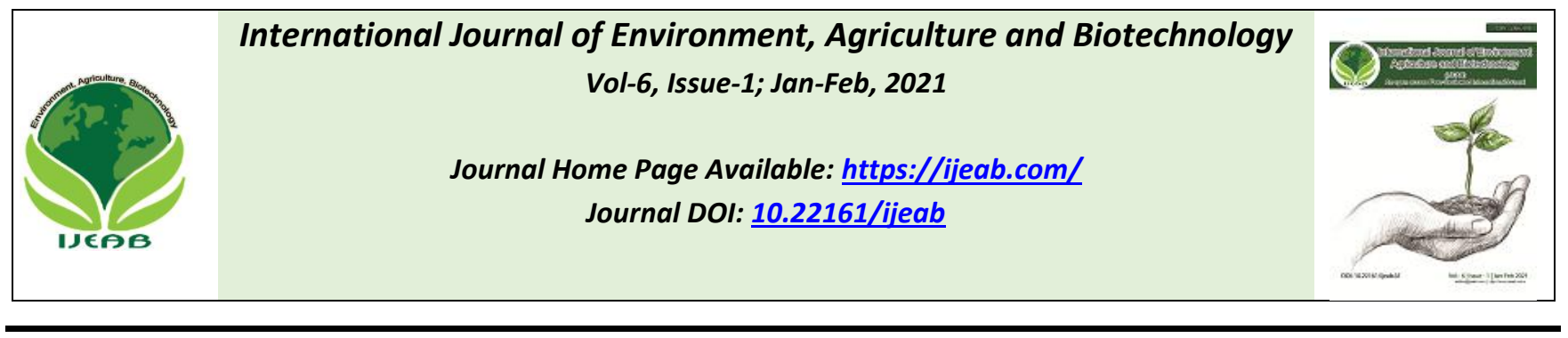

\title{
Determination of Heavy Metals Concentration in Soil around Sokoto Cement Company
}

\author{
M.M. Warrah ${ }^{1}$, Senchi D.S ${ }^{2}$, A.M. Bagudo ${ }^{1}$, U.M. Daboh ${ }^{1}$ \\ ${ }^{1}$ College of Agriculture Zuru, Kebbi State, Nigeria \\ ${ }^{2}$ Department of Pure and Applied Chemistry, Kebbi State University of Science \&Technology, Aliero, Nigeria
}

Received: 26 Nov 2020; Received in revised form: 22 Dec 2020; Accepted: 01 Jan 2021; Available online: 09 Jan 2021

(C)2021 The Author(s). Published by Infogain Publication. This is an open access article under the CC BY license

(https://creativecommons.org/licenses/by/4.0/).

\begin{abstract}
The main visible pollution generated by the cement industry corresponds to the dusts. The dusts can be emitted at every stage of the manufacturing process of the cement: extraction of the raw material, crushing, production. Eighty eight samples of soil were separately collected from the four directions of the company into polythene bags and brought to the laboratory for further analyses. The sample were digested using Aqua Regia Method, and the $\mathrm{Hg}, \mathrm{Zn}, \mathrm{Cd}, \mathrm{Cr}, \mathrm{Ni}, \mathrm{Pb}$ and $\mathrm{Cu}$ contents were determined by (AAS). Data generated were subjected to Analysis of Variance (ANOVA) to depict the differences and the means were separated with the Duncan Multiple Range Test (DMRT), where significant differences occur. It was found that the concentration of each heavy metal decreased with increase in distance from the industry. It was further found that heavy metals contributed differently to the pollution status of the environment with the eastern part impacting most. The concentration of heavy metals in the soil is high. The result of the analyses showed that $\mathrm{Hg}, \mathrm{Zn}, \mathrm{Cd}$ and $\mathrm{Cr}$ were high in the collected from four directions while $\mathrm{Pb}$ was foundto be the least. Sokoto Cement campany was found to produce the wastes/ dust that pollutes the environment.
\end{abstract}

Keywords - Heavy metals, Pollution, Dust, Cement and Soil.

\section{INTRODUCTION}

Owing to increasingly international concerns on the soil contamination due to $\mathrm{Cd}, \mathrm{Cr}$ and $\mathrm{Pb}$ (Williams and Robertson, 1999) there is need to probe into their effects. Cadmium, chromium and lead occur naturally in the environment and found in soil, plant, animals and human, typical as salts (Fleming and Parle, 1977). These metals can neither be destroyed nor degraded but can be converted to organic forms by biological action both in the environment and within living body (Eboget etal., 2008). However, some heavy metals at low doses are essential micronutrients for plants but in high doses they may cause metabolic disorders and growth inhibition for most of the plant species (Claire et al., 1991) Heavy metal contamination affects the biosphere in many places worldwide (Cunningham etal., 1997; Meagher, 2000). Lead, chromium and cadmium are highly toxic pollutants which can be added to the environment through automobile exhaust (Adriano, 1986). Inhibition of germination and retardation of plant growth are commonly observed due to lead toxicity (Igbal and Siddiqui, 1992). Cadmium is a heavy metal with high toxicity and has an elimination half-life of 10-30 years (Mortvert etal., 1981). Cadmium is very toxic to biological systems (Awofolu, 2005), the toxic effects of cadmium on growth and development of living organisms are well documented e.g. Servilla et al., (2005). However the molecular mechanism responsible for the inhibition of plant growth by cadmium is still not completely understood (Mecharg, 1994). Some authors suggested that both $\mathrm{Cd}$ and $\mathrm{Hg}$ showed drastic effects at high concentrations and longer duration with regard to seedling growth and metabolism (Madejon et al., 2002). Cadmium affects root metabolism, which shows sensitivity to $\mathrm{Cd}^{2+}$ toxicity by a reduction in lateral roots due to reductions in both new cell formation and cell 
elongation in the extensions region of the root. Farooq et al. (2009) observed that lead $(\mathrm{Pb})$ and cadmium $(\mathrm{Cd})$ toxicity affect seed germination, root and shoot seedling length, root ration and dry biomass of Albizia Lebbeck. They further stated that the tolerance of A. lebbeck seedlings to lead and cadmium gradually decreased with increasing concentration of the elements. Moreover, lead toxicity has been implicated in the decline of the Roman Empire (WHO, 1972). Their foods and drinking water was presumed to have been contaminated from lead guttering, and lead lined channels (Patterson et al., 1987; Fergusson, 1990). The recent autopsies on the remain of some expedition members preserved in the permafrost showed very high level of $\mathrm{Pb}$ sufficient to cause of lead poisoning (Patterson et al., 1987; Fergusson, 1990). Furthermore, Pb toxicity can result in abdominal pain, convulsions, sleeplessness, headache, e.t.c (WHO, 1972).

As one of the consequences of heavy metals contaminations in the soil, water and air, plants are also contaminated. Heavy metals get accumulated in plants and crops cultivated in heavy metals contaminated areas and when consumed by man and other live-stocks, they accumulate and reach lethal levels quickly (Fleming and Parle, 1977). $\mathrm{Cd}$ and $\mathrm{Cu}$ become concentrated during bio transfer from soil surface layer to plants, herbivores and their predators (Hunter etal., 1989). High tissue content of $\mathrm{Cu}$ and $\mathrm{Cd}$ were found in small mammals feeding on contaminated plant materials. Thus within the ecosystem, the principal route of transfer responsible for the mobilization of toxic metals would appear to be from the soil to vegetation (Hunter et al., 1989).However, people are exposed to cadmium by intake of contaminated food or by inhalation of tobacco smoke or polluted air (Lee et al., 1999). High concentration of cadmium in the soil represents a potential threat to human health because it is incorporated in the food chain mainly by plants uptake (Alvarez-Ayuso, 2008). In human, cadmium can cause anemia, cardiovascular diseases, growth impairment, alopecia, learning disorders, poor appetite, e.t.c. (WHO, 1972).

\section{MATERIALS AND METHODS}

\section{COLLECTION OF SAMPLES}

Eighty eight samples of twigs of soil samples were collected in the vicinity of the factory (between the months of August-October,2011) at interval of 50m from the mill, that is at (11) different points $(50 \mathrm{~m}, 100 \mathrm{~m}, 150 \mathrm{~m}, 200 \mathrm{~m}$, $250 \mathrm{~m}, 300 \mathrm{~m}, 350 \mathrm{~m}, 400 \mathrm{~m}, 450 \mathrm{~m}, 500 \mathrm{~m}$ and $1 \mathrm{~km}$ ) from the mill, in which $1 \mathrm{~km}$ served as Control point along each of the four cardinal points (i.e. East, West, South and North). The twigs of soil samples were collected and packed in clean polythene bags and taken to the laboratory for chemical analysis.

\section{COLLECTION OF SOIL}

Soil sample were collected from different points in each direction at $50 \mathrm{~m}$ interval and $1 \mathrm{~km}$ as control point by using measuring tape, hand glove and stainless steel soil Auger.The method of collecting the surface soil (the upper $3 \mathrm{~cm}$ layer) is according to the norm AFNOR X31B (AFNOR, 1999). The soil samples were packed in separately clean polythene bags and were taken to the laboratory for analysis.

\section{DETERMINATION OF HEAVY METALS IN THE} SOIL AND PLANT SAMPLES

The digested samples were separately analyzed for $\mathrm{Cd}, \mathrm{Cr}$, $\mathrm{Pb}, \mathrm{Ni}, \mathrm{Cu}, \mathrm{Zn}$ and $\mathrm{Hg}$ by Atomic absorption spectrophotometeric method. The radiation lamp for each heavy metal to be analyzed was placed in a compartment in the AAS and a tiny pipe attached to the machine (Aspirator) was put inside bottle containing the sample and the concentration of the respective heavy metal was read off by the aid of computer system attached to the machine.

\section{DATA ANALYSES}

Data generated from the quantification of heavy metals were subjected to descriptive and inferential statistics. Their concentrations were compared with respect to location/site with the use of analysis of variance (ANOVA). The means were separated with the use of Duncan multiple range test (DMRT). The data obtained from the chemical analysis were also subjected to statistical treatment using correlation coefficient matrices. This was carried out in order to establish association and probable source of dispersion or pollution. 


\section{RESULTS}

Table 1: Concentration of Cadmium $(\mathrm{mg} / \mathrm{l})$ in soil samples around Sokoto Cement Company

\begin{tabular}{lcccc}
\hline Distance $(\mathrm{m})$ & North & South & East & West \\
\hline 50 & 31.11 & 26.68 & 49.72 & 45.28 \\
100 & 30.68 & 26.01 & 50.11 & 44.99 \\
150 & 32.01 & 21.22 & 49.22 & 41.28 \\
200 & 33.14 & 19.98 & 48.98 & 42.01 \\
250 & 29.22 & 20.01 & 47.66 & 41.68 \\
300 & 30.01 & 18.68 & 48.14 & 41.72 \\
350 & 28.88 & 14.46 & 48.01 & 39.21 \\
400 & 28.68 & 15.01 & 47.77 & 38.99 \\
450 & 27.62 & 12.22 & 46.62 & 40.01 \\
500 & 26.44 & 10.22 & 47.01 & 37.98 \\
1000 & 2.19 & 1.51 & 2.23 & 2.12 \\
\hline
\end{tabular}

Table 2: Concentration of Chromium ( $\mathrm{mg} / \mathrm{l})$ in soil samples around Sokoto Cement Company

\begin{tabular}{lcccc}
\hline Distance $(\mathrm{m})$ & North & South & East & West \\
\hline 50 & 31.01 & 20.41 & 39.98 & 37.92 \\
100 & 29.68 & 20.41 & 39.99 & 37.77 \\
150 & 30.09 & 20.01 & 39.01 & 35.66 \\
200 & 30.61 & 19.92 & 39.01 & 35.66 \\
250 & 28.88 & 18.99 & 39.01 & 36.01 \\
300 & 29.21 & 18.01 & 38.66 & 35.81 \\
350 & 27.98 & 16.42 & 38.61 & 31.92 \\
400 & 27.69 & 11.21 & 39.03 & 34.01 \\
450 & 24.96 & 10.11 & 37.82 & 33.99 \\
500 & 24.68 & 10.14 & 38.01 & 33.66 \\
1000 & 1.11 & 1.09 & 2.03 & 1.32 \\
\hline
\end{tabular}

Table 3: Concentration of Copper $(\mathrm{mg} / \mathrm{l})$ in soil samples around Sokoto Cement Company

\begin{tabular}{lllll}
\hline Distance $(\mathrm{m})$ & North & South & East & West \\
\hline 50 & 16.48 & 13.11 & 27.96 & 23.92 \\
100 & 18.01 & 12.08 & 26.49 & 23.92 \\
150 & 17.22 & 11.21 & 27.99 & 24.01 \\
200 & 16.88 & 9.62 & 27.01 & 23.66 \\
250 & 15.96 & 9.88 & 26.11 & 22.66 \\
300 & 10.11 & 26.01 & 22.69 \\
350 & 9.01 & 27.12 & 22.11 \\
400 & 15.81 & 8.49 & 25.12 & 20.66 \\
450 & 14.99 & 7.99 & 24.28 & 19.99
\end{tabular}




$\begin{array}{lrrrr}500 & 12.22 & 8.42 & 24.28 & 21.08 \\ 1000 & 1.03 & 1.01 & 1.03 & 1.02\end{array}$

Table 4: Concentration of Mercury $(\mathrm{mg} / \mathrm{l})$ in soil samples around Sokoto Cement Company

\begin{tabular}{lccll}
\hline Distance $(\mathrm{m})$ & North & South & East & West \\
\hline 50 & 43.24 & 27.01 & 59.26 & 55.48 \\
100 & 41.91 & 26.42 & 59.48 & 54.99 \\
150 & 41.88 & 20.18 & 58.92 & 54.64 \\
200 & 38.46 & 18.08 & 59.02 & 55.01 \\
250 & 31.23 & 17.21 & 58.41 & 53.66 \\
300 & 34.01 & 16.92 & 56.68 & 53.76 \\
350 & 29.99 & 16.11 & 57.33 & 49.98 \\
400 & 31.21 & 15.68 & 58.14 & 51.04 \\
450 & 26.01 & 14.54 & 55.96 & 49.64 \\
500 & 26.66 & 14.54 & 56.01 & 50.50 \\
1000 & 2.03 & 1.91 & 3.99 & 2.21 \\
\hline
\end{tabular}

Table 5: Concentration of nickel $(\mathrm{mg} / \mathrm{l})$ in soil samples around Sokoto Cement Company

\begin{tabular}{lllll}
\hline Distance $(\mathrm{m})$ & North & South & East & West \\
\hline 50 & 31.22 & 18.98 & 49.68 & 45.69 \\
100 & 33.04 & 17.04 & 50.41 & 45.98 \\
150 & 30.48 & 12.22 & 50.01 & 45.66 \\
200 & 30.78 & 12.68 & 49.71 & 45.01 \\
250 & 26.11 & 11.92 & 49.01 & 44.21 \\
300 & 25.76 & 8.48 & 48.48 & 43.98 \\
350 & 24.92 & 6.42 & 48.71 & 39.21 \\
400 & 24.08 & 2.66 & 48.62 & 38.88 \\
450 & 21.41 & 5.82 & 46.46 & 37.68 \\
500 & 19.21 & 2.42 & 47.01 & 39.01 \\
1000 & 0.99 & 0.68 & 1.44 & 1.11 \\
\hline
\end{tabular}

Table 6: Concentration of Lead $(\mathrm{mg} / \mathrm{l})$ in soil samples around Sokoto Cement Company

\begin{tabular}{lllll}
\hline Distance $(\mathrm{m})$ & North & South & East & West \\
\hline 50 & 11.22 & 9.08 & 22.08 & 17.99 \\
100 & 12.13 & 9.21 & 22.66 & 18.22 \\
150 & 10.99 & 9.06 & 21.96 & 17.08 \\
200 & 11.01 & 9.01 & 21.81 & 15.66 \\
250 & 10.61 & 9.01 & 21.01 & 16.01 \\
300 & 10.48 & 9.01 & 20.69 & 17.21
\end{tabular}




\begin{tabular}{|c|c|c|c|c|}
\hline 350 & 9.99 & 8.98 & 20.02 & 14.28 \\
\hline 400 & 9.96 & 8.99 & 19.11 & 14.01 \\
\hline 450 & 9.61 & 9.01 & 18.98 & 13.99 \\
\hline 500 & 9.21 & 8.98 & 19.21 & 13.68 \\
\hline
\end{tabular}

1.01

Table 7: Concentration of Zinc $(\mathrm{mg} / \mathrm{l})$ in soil samples around Sokoto Cement Company

\begin{tabular}{lllll}
\hline Distance $(\mathrm{m})$ & North & South & East & West \\
\hline 50 & 37.88 & 26.08 & 58.08 & 47.99 \\
100 & 36.98 & 25.92 & 53.06 & 48.61 \\
150 & 36.04 & 20.01 & 53.68 & 47.92 \\
200 & 37.01 & 24.02 & 53.68 & 44.66 \\
250 & 30.48 & 19.68 & 52.99 & 45.31 \\
300 & 29.72 & 18.79 & 50.01 & 45.66 \\
350 & 16.01 & 49.66 & 43.96 \\
400 & 30.01 & 14.99 & 48.98 & 40.01 \\
450 & 29.61 & 15.01 & 49.81 & 44.03 \\
500 & 30.01 & 13.09 & 49.01 & 39.86 \\
1000 & 26.44 & 0.70 & 1.71 & 1.01 \\
\hline
\end{tabular}

\section{DISCUSSION}

This study shows a considerable abundance of the toxic metals on the soil around Sokoto Cement Company and its immediate environments.It was discovered that the concentrations of all the metals are higher in soil samples at various directions. The high concentration of the metals could be probably due to limited number of vegetation around the factory. The higher heavy metal concentrations observed in this study may be attributed to deposition of calcium oxide from Cement Company and calcium compounds in the soils of Sokoto. Brady and Weil (1999) reported that the neutral to alkaline soil $\mathrm{pH}$ observed in semi-arid soil such as that of Sokoto was due to low rainfall and alkaline compounds are not leached away, thus making soils of the region too alkaline. This is in support of the result of this study because the concentrations of cadmium $(\mathrm{Cd})$, chromium $(\mathrm{Cr})$, lead $(\mathrm{Pb})$, nickel $(\mathrm{Ni})$, copper $(\mathrm{Cu})$, zinc $(\mathrm{Zn})$ and mercury $(\mathrm{Hg})$ in plant and soil samples are high.

Gbadebo and Bankole (2007) analysed potentially toxic metals in airborne cement dust around Sagamu, Southwestern Nigeria. The heavy metals investigated are $\mathrm{As}, \mathrm{Al}, \mathrm{Ca}, \mathrm{Cd}, \mathrm{Pb}, \mathrm{Co}$, and $\mathrm{Zn}$. They reported elevated concentrations of these heavy metals and inducted them in the health problems among the inhabitants of the communities. Their observed confirmed favorably with the finding of this study. The result obtained in this study inducted potential environmental problems such as destruction of vegetation cover and environmental degradation (Topie, 1999; Hegazy,1996;). For example, Topie (1999) indicated that the cement industry was the main cause of destruction of vegetation cover and of environmental degradation in Solin and Kastela near Spilt, Croatia. Damages to coniferous trees by cement dust have been reported by Mandre and Tuulmets (1997).

Cement dust had a significant effect on the growth of some plant species compared with non-cement dusted plants. Toxic compounds such as fluoride, magnesium, lead, zinc, copper, beryllium, sulfuric acid and hydrochloric acid were found to be emitted by cement manufacturing plants (Andrej, 1987).This support the result of this study which showed that cadmium, chromium, copper, mercury, nickel, lead and zinc are available in soil around Sokoto Cement Company. Reduction in plant height, cover and number of leaves of $C$. carandas showed that the losses can generally be attributed to the cement dust which contained toxic metals. The results obtained are in close conformity with those reported by Stratmann and Van Haut (1966) who dusted plants with dust ranging from 1 to $48 \mathrm{~g} / \mathrm{m}^{2}$ day $^{-1}$ and concluded that dust falling on the soil caused a shift in $\mathrm{pH}$ to the alkaline side. The findings of Prasad and Inamdar (1990) in Vignamungo (Black gram) also 
confirmed the finding of this study. The cement dust kiln showed a reduction in chlorophyll content, protein, starch, yield and phytomass in ground nuts (Arachis hypogaea L.) (Liu et al., 1997) reported that cement dust decreased the yield of grape and rice in the vicinity of a cement factory in China. It has also been indicted in the reduction of crop yield.Plant response varies between species of a given genus and between varieties within a given species. Plants do not necessarily show similar susceptibility to different pollutants. Major variations in response to different species to air pollutants have been documented by Jacobson and Hill (1970). Studies of biochemical changes and pollution effects on the plant metabolism, i.e., reduction in chlorophyll and completely clogged stomates (Ahmed and Qadir, 1975) revealed that these parameters are important in regulating the productivity and also the number of flowers and seeds produced.

Cadmium, chromium, copper, mercury, nickel, lead and zinc that are prominent in cement dust were found to be higher in concentration in the samples analyzed. This indicates the extent to which the soil and vegetation were polluted by the cement dust from the Sokoto cement company. The concentrations of heavy metals are higher in eastern and western part followed by north and least was southern part of the company, the higher concentrations of heavy metals in eastern and western parts was attributed due to the loading of Cement and heavy trucks movement in the east and presence of quarry and production activities in western part of the Company. Ade-Ademilua and Umebese (2007) have pointed out that metal to metal association could cause an increase in concentration of other metal (absent in cement dust) in the polluted soil over time. Forstner (1995) also pointed out that $70 \%$ of metals contaminated soils involved two or more metals and the possibility of synergistic effects may be of considerable importance at some heavy metals contaminated sites.

The significant reductions in shoot length and total leaf area observed in the polluted plants have also been reported in the works of Singh and Rao (1981); Ayanbamiji (1996) and Igbal and shafoeg (1998). The reduction may be due to toxicity of heavy metals which Rout etal.(2000) stated that once inside the cells, the aluminium could inhibit root absorption and growth in both aluminium sensitive and tolerant plants. The significant decrease in vegetative growth of polluted plants may be an indication of a reduction in photosynthesis of polluted plants which could be explained on the bases of quantitative as well as qualitative changes in the incident light available for photosynthesis in cement encrusted leaves (Bohne,1963), interruption in gaseous through stomatal clogging (Darley etal.,1966), reduction in transpiration in terms of the absorption of minerals from soil and inhibition of intracellular processes (Singh and Rao,1981).

The cement dust caused the epidermal cells and stomata of the polluted leaves to become modified.The higher stomata frequency and index in the leaves of the polluted plants indicate morphological modification on the leaves. According to Ayanbamiji (1996), these may be adaptations for gaseous exchange and transpiration since the surfaces are covered by cement dust.Studies of the effects of cement-kiln dust deposited on the soils also raised questions. Some investigators reported no harmful effects of cement at levels from 1.5 to $7.5 \mathrm{~g} / \mathrm{m}^{2} /$ day, while others reported that concentrations from 1.0 to $48 \mathrm{~g} / \mathrm{m}^{2} /$ day caused shifts in the soil alkalinity which may be favorable to one crop but harmful to others (Lerman and Darley, 1975) thus confirming the result of this study whose reported higher concentrations of heavy metal in soil samples.Abdulrahman et al. (2007), on the analytical assessment of some trace metals in soils around the major industrial areas of Northwestern Nigeria and Sokoto Cement Company reported higher mean concentrations of heavy metals: $\mathrm{Cd}$ (0.10 ug/g); $\mathrm{Cr}(83.4 \mathrm{ug} / \mathrm{g}) ; \mathrm{Pb}(486 \mathrm{ug} / \mathrm{g})$ and $\mathrm{Ni}(22.9 \mathrm{ug} / \mathrm{g})$. This study also showed higher concentration of heavy metals investigated, the mean values are $\mathrm{Cd}(16.9 \mathrm{mg} / \mathrm{l}), \mathrm{Cr}(15.2 \mathrm{mg} / \mathrm{l}), \mathrm{Pb}(8.30 \mathrm{mg} / \mathrm{l})$ and $\mathrm{Ni}(9.03 \mathrm{mg} / \mathrm{l})$ which are within the range reported by Abubakar etal (2006); Birnin Yauri and Argungu (2002).

Adejumo et al. (1994) showed that some toxic heavy metals like arsenic (AS), lead (Pb,) nickel (Ni), cobalt $(\mathrm{Co})$, zinc $(\mathrm{Zn})$, copper $(\mathrm{Cu})$ and phosphorus $(\mathrm{P})$ were significantly enriched in the neighbourhood of cement factories in Nigeria. This can lead to reduction of soil fertility, Adejumo et al., (1994); Sivakumar et al., (1995), it has also been linked to the damage of dwellings (Wasserbauer etal., 1998). Deposit of cement dust on roofs can cause microbiological and chemical disintegration of the roofs. Wasserbauer etal. (1998) indicated that metabolic process of nitrifying bacteria (mainly Nitrosomonas and Nitrobacter) on cement dust which settle on roofs can cause chemical corrosion of the roofing materials thereby increasing porosity and weakening the strength of roofing materials.

On the basis of this study, it could be said that vegetation and soil around Sokoto Cement Company was found to be affected by cement dust, which might be due to the presence of different toxic pollutants in cement dust. The biological behavior of vegetation e.g.A nilotica was found to be highly affected due to the present of different heavy metals found in the twig of the plant. It is clear that the cement dust pollution is an operative ecological factor causing deterioration in the quality of our environment 
(Shah etal. 1989). It is concluded that the presence of toxic pollutants in cement dust might be responsible for the reduction in vegetation and soil fertility. Traces of toxic metals such as chromium and copper are common in some varieties of Portland cement and are harmful to human beings and other living systems (Omar and Jasim, 1990). The heavy metals present in the cement dust can play an important role in disturbing the various metabolic processes of plant. The growth metabolic processes and yield of winter barley were found to be affected by the Duna cement and lime works (Borka, 1986), in an experiment of six kinds of dust which contained heavy metals introduced under the stand canopy. The dust was collected from zinc, cadmium, aluminum, iron plants, electric power station and the cement plant. The dust was introduced in concentrations of 100, 500, 1000, 2000 and $5000 \mathrm{t} \mathrm{Km}^{-2}$. The experiment proved that the cement dust brought about changes in the ecosystem. A link between the forest ecosystem under the influence of heavy metals in dust and the effect of these changes on the growth of pine stands was also obtained.

The levels at which the toxic elements were found in soil sample around the factory in this study showed that they have exceeded regulatory standards, $\mathrm{Cd}\left(0.005 \mathrm{ug} \mathrm{g-}^{-1}\right) ; \mathrm{Cr}$ (0.02ug g- $\left.{ }^{1}\right)$; $\mathrm{Pb}\left(0.05 \mathrm{ug} \mathrm{g-}^{1}\right)$ and $\mathrm{Ni}\left(0.5 \mathrm{ug} \mathrm{g-}^{1}\right)$ WHO (1971). It showed that the cement plant is seriously polluting the environment and it confirmed the assertion of Bilen (2010) that cement production is of the main sources of environmental pollution. It also showed that control strategies for prevention of dust release by cement plants have not been implemented in the cement company. Fell et al. (2003) said that in advanced countries, controlstrategies for the prevention of dust release by machinery enclosure, local exhaust ventilation, work automation and greater diligence in maintenance of machinery have been implemented, presumably leading to less dust exposure.

\section{CONCLUSION}

This study has shown that there is a significant emission of cement dust into the environment around Sokoto Cement Company, up to $1000 \mathrm{~m}$ distances from the mill in the four cardinal directions. This dusts emitted are capable of posing a serious problem to the soil fertility even at a distance of $1000 \mathrm{~m}$ away from the mill. This study has established that higher concentrations of heavy metals in soil samples $(\mathrm{Cd}, \mathrm{Cr}, \mathrm{Cu}, \mathrm{Hg}, \mathrm{Pb}, \mathrm{Ni}$ and $\mathrm{Zn}$ ) were obtained in different locations. It could be concluded that soil around Sokoto Cement Company were found to be affected by cement dust, which might be due to the presence of different toxic pollutants in cement dust. It was found that the concentrations of heavy metals were highest in eastern part followed by western then the northern part and the least was southern part of the company. It is clear that the cement dust pollution is an operative ecological factor causing deterioration in the quality of our environment (Shah etal., 1989).

I therefore recommend that to safeguard the quality of the soil around the company, the cement factory management should embark on regular/periodic monitoring of cement dust level in and around the factory environment, and should reduce the dust emission by the use of dust filters.

\section{REFERENCES}

[1] Abdulrahman, F.W. Inuwa, M. Birnin Yauri, U.A. and Ibrahim, S.A. (2007). Analytical assessments of some trace metals in Soils around the major industrial Areas of Northern Nigeria. Academic Journals Inc., (2) 6: 515-521.

[2] Abubakar, U. Adamu, T and Ishaku, N.T. (2006). Prevalence of Urinary Schistosomiasis Among Inhabitants of Four Local government of Sokoto State. Nigeria journal of Basic and Applied Sciences Vol. 14 (1\&2). P 23

[3] Ade-Ademilua, O.E. and Umebese, (2007). The growth of Phaseolus vulgaris L.CV. Ife Brown (Leguminosae) in a cement side rich in heavy metals.Pak. J. Biol. Sci., 10(1): 182-185.

[4] Adejumo, J.A. Obioh, I.B. Ogunsola, O.J. Akeredolu, A.F. Olaniyi, H.B.Asubiojo, O.I. Oluwole, F.A.'Akanle, O.A. and Spyrou, N.M.(1994)."The Atmospheric Deposition of major, minor and trace elementswithin and around three cement factories." Journal of Radio Analytical and NuclearChemistry, 179(2): 195-204

[5] AFNOR, (1999). Recueil de normes françaises: qualité dessols, Vol. 1, France.

[6] Ahmed Z. and Qadir S.A (1975). The effects of air pollution on stomatalclogging, carbohydrate and chlorophyll contents in certain roadside plants.

Pakistan Journal of Botany 7: 81-84.

[7] Andrej, J. (1987). Bees and their products as indicators of environment pollution. Med Weter 43(6): 352-356.

[8] Andriano, D.C. (1986). Trace element in the terrestrial environment. Springer. Verlag, New York, Pp: 533.

[9] Awofolu, O.R. (2005). A survey of trace metals in vegetation, soil and lower animals along some selected major roads in metropolitan city of Lagos. Environmental Monitoring and Assessment, 105: 431-447.

[10] Ayanbamiji, T.A. (1996). The effect of cement dust on some plant growing in the surrounding of Africa Portland cement Company, Ewekoro. Morphology and level of calcium, iron, silicon and aluminium. M.Sc Thesis, University of Lagos, Nigeria.

[11] Bilen, S. (2010). Effect of cement dust pollution on microbial properties and enzyme activities in cultivated and no-till soils. Afr. J. Microbiol. Res., 4:2418-2425.

[12] Bohne, H. (1963). Schädlichkeit von Staub aus Zementwerken für Waldbestände. Allg. Forst., 18, 107111. 
[13] Borka, G. (1986). Effects of cement dust on the growth development, major metabolic processes and yield of winter barley Òin situÓ and under controlled conditions. Acta Agron Hungary 35(1/2): 45-52.

[14] Brady, N.C. and Weil, R.P. (1999). The nature and properties of soil: twefth edition. Upper saddle River. $N \mathrm{~J}$; prentice Hall. Pp 446-490.

[15] Darley, G.D.E.F. Drugger, W.M. Mudd, J.B. Ordin, L. Taylor, O.C, and Stephe ， E.R. (1966). Plant damage by pollution derived from auto mobiles. Arch Environment Health 6: 700-761.

[16] Ebog, G.A. Apkan, M.M. and Mkpenie, V.N. (2008). Heavy metal contents of municipal and rural, Dumpsite soils and rate of accumulation by Carica papaya and Talinum triangulare in uyo, Nigeria, Akpan, Nigeria. Pp 23-56

[17] Farooqi, Z.R. Zafar, J.M. Kabir, M. and Shafig, M. (2009). Toxic effects of lead and cadmium on germination seedling growth of Albezia lebbeck L. Pak. J Bot., 41(1): 27-33.

[18] Fell, A.K.M. Thomassen, T.R. Kristensen, P. Egeland, T. and Kongerud, J. (2003). Respiratory symptoms and ventilatory function in workers exposed to Portland cement dust. J. Occup. Environ. Med., 45: 1008- 1014

[19] Fergusson, J.E. (1990). The Heavy elements: Chemistry, Environmental impact and Health Effects.Pergamon Press, Oxford. Pp 18-19, 55-79.

[20] Fleming, G. and Parle, P. (1977). Heavy metals in soils, herbage and vegetables from an industrialized area west of Dublin city. (rish). Agric. Res., 16: 35-48.

[21] Forsner, V. (1995). Land contamination of metals .In: Metals speciation and contamination of soil, Allen, $\mathrm{H}$. (Ed). Lewis publishers, London, PP: 1-33.

[22] Gbadebo, A.M. and Bankole, O.D. (2007). Analysis of potentially toxic metals in airborne cement dust around sagamu, Southwestern Nigeria. J. Applied Sci., 7: 35-40.

[23] Hegazy, A.K. (1996). "Effect of cement kiln dust pollution on the vegetation and seed bank species diversity in the eastern desert of Egypt." Environmental Conservation, 23(3): 249-252.

[24] Hunter, B.A. Johnson, M.S. and Thompsom. D.J. (1989). Ecotoxicology of $\mathrm{Cu}$ and $\mathrm{Cd}$ in a contaminated grassland ecosystem. 11. Journal of Applied Ecology, 24(2): 573-586

[25] Igbal, M.Z. and Siddiqui, D.A. (1992). Effects of lead toxicity on seed germination and seedling growth of some tree species. Pakistan Journal of Scientific and Industrial Research, 35: 139-144.

[26] Iqbal, M.Z. and Shafoeg, M. (1998). Toxicity of cement dusts on the growth of some tree seedlings. EcologiaBratislava, 17: 434-439.

[27] Lee, Y.Z. Sazuki, S. Kawada, T. Wang, J. Koyama, H. Rivai, I.F. and Herawati, N. (1999). Content of cadmium in carrots compared with rice in Japan, Bull. Environ. Contan. Toxico. 63: 711-719.

[28] Lerman, S.L. Darley, E.F. (1975). Particulates, In. Responses of Plants to Air Pollution. Pp. 141. New York: Academic Press.
[29] Lerman, S.L. Darley, E.F. (1975). Particulates, In. Responses of Plants to Air Pollution. Pp. 141. New York: Academic Press.

[30] Liu, J.L. Du, M. Shang, K.Y. Chen, S.Y. Xu, H.B. and Xie, M.Y. (1997). The effects of cement dust pollution on rice, rape and soil. J Plant Resources Environ 6, 42-47.

[31] Madejon, P. Murillo J.M. Maranon, T. Cabrena, F. and Lopez, R. (2002). Bioaccumulation of $\mathrm{As}, \mathrm{Cd}, \mathrm{Cu}, \mathrm{Fe}$, and $\mathrm{Pb}$ in wild grasses affected by the aznalcollar mine spill (SW spain) Sci. Total Environ., 290: 105-120.

[32] Mandre, M. and Tuulmets, L. (1997). "Biochemical diagnosis of forest decline.” Baltic Forestry, 3 (2): 19-25

[33] Mecharg, A.A. (1994). Integrated tolerance mechanism constitutive and adaptive plant responses to elevated metal concentrations in environment.Plant Cell and Environment. 17: 989-993.

[34] Mortvedt, J. Mays, D.A. and Osborn, G. (1981). Uptake by wheat of cadmium and other heavy metals contaminants in phosphate fertilizers. J Environ. Quality, 10: 193-197.

[35] Omar, J.M. and Jasim, F. (1990). Some observations on the use of electrothermal atomic absorption spectorpotometry for the determination of chromium and copper in Portland cement. Microchemistry Journal 41(3): 348-355.

[36] Patterson, C.C. Shirahata, H. and Ericson, J.R. (1987). Pb in ancient human bones and its relevance of historic developments of social problems with pub. Science of the Total Environment, 61: 167-200.

[37] Servilia, O. Foca, N. and Ainnei, A. (2005). Effects of heavy metal on plant growth and photosynthetic activity. Unpublished M.sc thesis. University of Agriculture sciences and veterinary medicine, lasi. Pp. 107-110.

[38] Shah, F.H. Ilahi, I. and Rashid, A. (1989). Effect of cement dust on the chlorophyll contents, stomatal clogging and biomass of some selected plants. Pakistan J Sci Indust Research 32(8): 542-545.

[39] Singh, S. N. and Rao, D. N. (1981). Certain responses of wheat plants to cement dust pollution. Environ. Pollut., A24, 75.78 .

[40] Topie, V. (1999). "Surface excavation in the area of kastela and the possibilities of Amelioration." SurmarkiList, 123(7-8): 301-309.

[41] Wasserbauer, R. Z. Zadak and Novotry, J. (1998). "Nitrifying bacteria on the asbestos cement roots of stable buildings." International Biodeterioration, 24(3): 153-165.

[42] Williams, O. and Robertson, B. (1999). The role of heavy metals in human metabolism. Environmental Pollution, 42:5.

[43] Birnin Yauri, U.A.B. and Argungu, B.H. (2002). Automobile pollution, a case study of some towns in kebbi state Nigeria. Nig. J. Basic Applied Sci., 11: 147-155.

[44] World Health Organization (WHO) (1972). Health hazards of the human environment; Geneva, Zealand state high with low traffic volume. Environmental pollution 18: 265274. 